sterone in organisms might also have its origin in a partial hydrogenation of androstene-dione. Thus a possible explanation is obtained for the simultaneous occurrence of the male and female hormones in one organism.

The appearance of different hormones with similar action in organisms leads to the question of the relationship between their constitution and physiological action, and, furthermore, to the question of the chemical specificity of hormone action. The specificity is most evident in progesterone, which as yet is the only compound possessing the complete characteristic corpus luteum hormone action. The specificity of the hormones in the cestrane group (VII-XI) is no doubt considerably smaller, as they all show approximately the same qualitative action, the main point of difference being merely a quantitative one. In all the hormones of the cestrane group the phenolic ring is present unchanged, whereas in contrast, this ring in the androstane group (III-VI) is variable, and this group of hormones is accordingly characterised by the largest number of compounds which, in spite of differences in chemical structure, yet show very similar physiological action.

The formulæ (III-VI) give only a partial indication of the possible variations in the androstane group. We have recently discussed ${ }^{13}$ more than twenty physiologically active androstane derivatives in which relationships between constitution and action can be undoubtedly recognised. These investigations involved the preparation of the 17-methyl-testosterone, which according to preliminary results seems to show an activity on the sex glands of castrated rats slightly higher even than that of testosterone. In different laboratories and medical research institutes, the most powerful of these compounds, especially testosterone, have been subjected to a thorough investigation, which should provide the answer to the question as to range of the physiological action of the male hormones in healthy and diseased organisms.

\footnotetext{
B. Zondek, NATure, 133, 209, $494 ; 1934$.

E. Tschopp, Praxis, Schweiz. Rundschau für Medizin, December 12, 1935, and Arch. internat. Pharmacodyn. et Therapie, January, 1936. $758 ; 1934$.

' Cf. the latest paper in this field by A. Cohen, J. W. Cook and C. L. Hewett, J. Chem. Soc., 445; 1935 .

R. V. Ruzicka and A. Wettstein, Helv. Chim. Acta, 18, 986 ; 1935. R. Oppenauer, NATURE, 135,$1039 ; 1935$. W. Schoeller, A. Only the latest papers are mentioned. 1935.

Callow and $\mathbf{R}$. Deanesly, Biochem. $J$., 29, $1424 ; 1935$. Lancet, ii, 77; 1935. A. Parkes, Chem and Ind, 928; 1935. V. Korenchevsky, M. Dennison and S. L Simpson, Biochem, $J$ 2131; 1935. V. Korenchevst and S. L. Simpson, Biochem. J., 29, 2131; 1935. V. Korenchevsky, internat. Pharmacodyn. Therapie.

Freud and E. Laqueur, NATURE, 125 $184 ; 1935$.

${ }^{8}$ E. Laqueur, P. de Fremery, J. Freud, S. E. de Jongh, S. Kober A. Luchs and A. P. Münch, Berichte über die gesammte Physiologie, 6 1931. T. F. Gallagher and F. C. Koch, Endocrinology, 18, 107; 1934. Matsuzaki Kwanji, Jap. J. Med. Sci., 7, 1515; 1934.

E. Tschopp, NATURE, 136, 258; 1935.

${ }^{10} \mathrm{~K}$. David, E. Dingemanse, J. Freud and E. Laqueur, Z. physiolog. Chem., 233, $281 ; 1935$.

11 K. David, Acta brev. Neérland., 5, 85, 108 ; 1935

${ }^{19} \mathrm{~L}$. Ruzicka and A. Wettstein, Helv. Chim. Acta, 18, $1264 ; 1935$. A. Butenandt and G. Hanisch, Ber. Deutsch. Chem. Ges., 68, 1859 ; 1935 .

${ }_{13}$ L. Ruzicka, M. W. Goldberg and H. R. Rosenberg, Helv. Chim. Acta, 18,$1487 ; 1935$.
}

\title{
Obituary
}

\section{Dr. R. G. Canti}

$\mathrm{B}^{\mathrm{x}}$ $Y$ the death of Dr. Ronald George Canti on January 8 at the early age of fifty-two years, the medical profession loses not only a distinguished consulting pathologist but also a brilliant experimental investigator.

Borm in 1883, Canti was educated at Charterhouse, King's College, Cambridge, and St. Bartholomew's Hospital, London. After graduating in medicine he became house physician to the late Dr. Samuel West, and in 1915 joined the teaching staff of St. Bartholomew's Hospital as a demonstrator of pathology. $\mathrm{He}_{\Theta}$ remained a member of the Pathological Department until his death, being successively senior demonstrator of pathology, bacteriologist to the hospital, and ultimately clinical pathologist and medical officer of health to the hospital. In addition to his hospital work, he carried on a large private consulting practice as a pathologist. In all matters relating to his profession he was an acknowledged master. The late Sir Frederick Andrewes, whose senior assistant he had been for many years, was wont to declare that Canti was the finest clinical pathologist he had ever known.
The heavy demands of private practice, and the routine work connected with his hospital appointments, would have taxed the energies of any ordinary person. But Canti was no ordinary person. He was indefatigable. His quick intelligence, vivid imagina. tion, wide knowledge and superlative technical skill, were always at the disposal of his colleagues and friends, and continually being used by them.

Canti's chief claim to public recognition, however, is the brilliant scientific work which he carried out during the past dozen years on the development of normal and malignant cells and their response to radiation. Active participation in the intensive clinical research on the effects of $X$ - and radium rays on cancer, which was carried out by the staff of St. Bartholomew's Hospital immediately after the close of the Great War, convinced him that progress was greatly retarded by the prevailing ignorance of the fundamental action of these agents on living cells.

Further consideration led Canti and one or two other Bart's men to recognise that the late Dr. T. S. P. Strangeways had so perfected the art of cultivating living tissues in vitro as to afford an 
almost ideal laboratory method of studying such effects. They joined him to form the Strangeways team for an attack on these problems. A programme of radiological research extending over a number of years was drawn up which, with some modifications, is still being pursued by several of the members of the Strangeways Research Laboratory.

The programme included the investigation of the earliest observable effects of irradiation; immediate and delayed lesions and lethal action; growth stimulation and retardation; vulnerability in relation to the various phases of the life-cycle; relative efficiencies of intermittent and continued irradiation ; variation in response due to changes of quality and intensity; and the separation of direct from indirect actions. Canti's genius showed itself in the many new instruments, appliances and techniques which he evolved to elucidate these problems and in the valuable results obtained by him and his collaborators which are published in numerous papers in various radiological and biological journals. Special reference must be made to the now world-famous cinema photomicrographic study which he made on the effects of gamma rays on normal and malignant cells grown in vitro. The first apparatus used by Canti for this purpose was constructed from Meccano parts and erected by him in his private house. With it he secured the superb photomicrographs which are now shown in all the continents of the world, and have probably been the means of convincing more people of the efficacy of the radiation treatment of cancer than any other form of publication. For this work Canti received the Röntgen award of the British Institute of Radiology and shared with other members of the Strangeways Research Laboratory the Garton prize of the British Empire Cancer Campaign.

At the time of his death Canti was honorary secretary to the Scientific Advisory Committee of the British Empire Cancer Campaign, to the Cancer Research Committee of St. Bartholomew's Hospital, and scientific adviser to the British Red Cross Blood Transfusion Service. His distinguished appearance, his modesty and great personal charm impressed everyone with whom he came in contact. His loss will be deeply felt by a very wide circle.

In 1912 Canti married Clare Eyles, who nursed him through his last long illness which terminated in pneumonia. He leaves four children, of whom the youngest son is at present a student at St. Bartholomow's Hospital.

F. L. H.

\section{Dr. Herbert Bolton}

Dr. Herbert Bolton, director of the Bristol Museum and Art Gallery from 1898 until 1930, died on January 18 at Reading, whence he retired in 1931. Dr. Bolton was born at Bacup, Lancashire, in 1863 and started life as a boy in the mills. He applied himself to the rigid discipline of self-education through the medium of the oldfashioned night schools, and eventually proceeded to the Royal College of Science, South Kensington, where he was a fellow student with $H$. G. Wells and Morley Davies. He afterwards went to Owens
College, Manchester, and in 1890 was appointed to an assistant keepership in the Manchester Museum.

During this period, Bolton pursued several lines of geological research, but even in these early days he was chiefly attracted by the stratigraphy and palæontology of the Coal Measures. His most important contributions to science at this stage include the publication in 1898 of a critical survey of the nomenclature of the seams in the Lower Coal Measures of Lancashire, and the palæontology of the Manx Slates, Isle of Man, in 1899. He was elected a fellow of the Royal Society of Edinburgh in 1894.

Dr. Bolton's real life-work and interest began when he was appointed curator of the Bristol Museum in 1898. He became the first director of the Museum and Art Gallery in 1911 and ably served the city of his adoption for thirty-two years. During this period the exhibition area was increased three-fold and the whole of the material was entirely recased. He always tried to visualise the visitors' point of view, and formulated many museum principles which are to-day universally accepted. Indeed many of the so-called new themes in museology expounded at the present time are to be found in his presidential address at the Wembley Conference of the Museums Association in 1924. Several of the younger generation of museum curators can testify to the intensive and extensive methods of his training. A strict disciplinarian, a ruthless but honest critic, he would first destroy the theme put forward by the budding curator and then by constructive and suggestive means gradually evolve the true solution of any museum problem. A hard and severe training it was, although many have had reason to be thankful for contact with such an inspiring and vitalising personality.

Pre-eminence in the museum world was acknowledged by Dr. Bolton's membership of the Advisory Council of the Victoria and Albert Museum in 192033 and by the invitation to give evidence before the Royal Commission on National Museums. At various times he had the opportunity and privilege of visiting the most important museums in Europe, Australia, Canada and America.

Throughout his life, Dr. Bolton always stressed the idea that curatorial work and research were complementary, and reacted both to the benefit of the curator and the institution. He put this theory into practice, and considering that throughout his time at Bristol administrative duties were continually increasing, the amount of original research that he published must be regarded as remarkable. For many years he was reader in palæontology and a member of the Court of the University of Bristol.

In 1907 and 1911 Dr. Bolton published papers on the faunal horizons in the Coal Measures of the Bristol district. In view of the fact that several of these collieries are now closed, the evidence he recorded and the specimens he collected are important. Afterwards, he became interested in several other local geological questions, but finally was inevitably drawn to the small compact group of Carboniferous insects. With Mr. J. W. Tutcher as collaborator in photography, he wrote several papers on these hitherto neglected forms. The paper in which he graphically 